\title{
Risk assessment of boron in glass wool insulation
}

\author{
Allan Astrup Jensen \\ Received: 4 October 2007 / Accepted: 9 October 2008 / Published online: 8 November 2008 \\ (C) The Author(s) 2008. This article is published with open access at Springerlink.com
}

\begin{abstract}
Background, aim and scope Glass wools are man-made vitreous fibres, which consist principally of sodium, calcium and magnesium silicates, but may contain smaller amounts of other elements, including boron. The boron contents originate from the use of borates in the glass melting process as a glass former and a flux agent. During the production and application of glass wool insulation products, workers may legally be exposed to glass fibre up to the occupational limit value, commonly of 1 fibre $/ \mathrm{cm}^{3}$. However, in practice, the fibre exposure will be at least ten times lower. Boron is a non-metallic element widely distributed in nature, where it occurs as boric acid, borates and borosilicates. Humans are mainly exposed to boron via vegetarian food and drinking water, mineral supplements and various consumer products. Boron is an essential element for plant growth, but the essentiality for humans is not proven, although intakes of trace amounts of the element seem to be useful for bone health and proper brain function; higher concentrations of boron, however, may be toxic. In relation to the European Union legislation on dangerous substances, an EU Expert Group has recommended classifying boric acid and borates with risk phrases for reproductive toxicity. The aim of this paper is to assess whether the new EU hazard classification of boron compounds should imply that glass wool products used for building insulation in the future should be labelled, "may impair fertility and cause harm to the unborn child", because of the low boron content.
\end{abstract}

A. A. Jensen $(\square)$

FORCE Technology,

345 Park Allé,

2605 Broendby, Denmark

e-mail: aaj@force.dk
Materials and methods Boron intakes are estimated in a worst-case occupational situation with human exposure to glass wool fibres at the occupational limit of 1 fibre $/ \mathrm{cm}^{3}$ by calculation of the mass of the amount of fibres inhaled during an 8-h work day. Fibres are supposed to be cylinders of glass with a length of $30 \mu \mathrm{m}$, an average diameter of $1.5-2 \mu \mathrm{m}$ and containing either $1.5 \%$ or $3.5 \%$ boron. As a worst-case scenario, the density of the fibres is set to $2,700 \mathrm{~kg} / \mathrm{m}^{3}$. The inhalation rate of the individuals at moderate work load was set to $2 \mathrm{~m}^{3} / \mathrm{h}$. A worst-case scenario also corresponds to $100 \%$ retention and to $100 \%$ solubility of the retained fibres in the lungs.

Results With the normal boron content of $1.5 \%$ in glass wool fibres for building insulation, the extra daily occupational boron intake/uptake will be $0.03-0.06 \mathrm{mg} \mathrm{B}$ for 5 days a week. For more uncommon glass wool with maximum boron content of $3.5 \%$, the worst-case daily boron intake/uptake will be $0.08-0.16 \mathrm{mg}$ B. The main boron exposure in the general population is from vegetarian food, and the average daily dietary intake with food is estimated to $1.2-1.5 \mathrm{mg} \mathrm{B} /$ day. In addition, significant intakes may come with drinking water, especially from mineral water. In some instances, exposure from mineral supplements, cosmetics and other consumer products may be significant. For example, individuals taking mineral supplements, e.g. for bodybuilding, may have an additional intake to that of $1-10 \mathrm{mg} /$ day. During the years, various organisations have recommended safe intake values for boron. Recently, the Scientific Panel on Dietetic Products, Nutrition and Allergies of the European Food Safety Authority (EFSA) has established the 'Tolerable Upper Intake Level' (UL) for the intake of boron (boric acid and borates) at $0.16 \mathrm{mg} \mathrm{B} / \mathrm{kg}$ body weight per day or about $10 \mathrm{mg} \mathrm{B} /$ day for an adult.

Discussion The calculated, worst-case exposure scenario during an 8-h work day will result in an extra daily boron 
intake that only corresponds to about $10 \%$ of the average daily adult boron intakes through food and drinks of about $1.5 \mathrm{mg}$. The inter-individual variations in boron intakes from foods, water and supplements will be much greater than an eventual, very worst-case, additional intake of boron from inhalation of glass wool fibres. In addition, the combined intakes are far lower than the 'Tolerable Upper Intake Level' of $10 \mathrm{mg} \mathrm{B/day} \mathrm{for} \mathrm{a} \mathrm{person} \mathrm{weighing} 60 \mathrm{~kg}$, as recommended by the European Food Safety Agency. The potential boron intake from inhalation of glass wool fibres is also much lower than boron intakes by workers in the boron industry, who at the present occupational limit value will be exposed to $50 \mathrm{mg}$ of boron 5 days a week, or 100 times more than the worst case for glass wool fibres. Furthermore, in practice, exposure levels will mostly be ten to 100 times lower than the occupational limit used here as a worst case.

Conclusions The estimated boron intake from inhalation of glass wool fibres in occupational settings will be insignificant and without any health risks, even in the case of noncompliance with the occupational limit value. Any proposal requiring hazard labels on commercial glass wool products for building insulation, because of the boron content, is not supported by the present scientific knowledge.

Recommendations and perspectives The European Commission should ensure that the new EU hazard classification of boron compounds is not applied to commercial glass wool products for building insulation having a low content of boron.

Keywords Boron · Boron compounds · Boron intake - Glass wool insulation $\cdot$ Occupational exposure $\cdot$ Risk assessment

\section{Background, aim and scope}

\subsection{Glass wool}

Glass wools are man-made vitreous fibres, which consist principally of sodium, calcium and magnesium silicates, but may contain smaller amounts of other elements, including boron. The raw materials for introduction of boron into glass wool are mainly mined colemanite $\left(\mathrm{Ca}_{2} \mathrm{~B}_{6} \mathrm{O}_{11} \cdot 5 \mathrm{H}_{2} \mathrm{O}\right)$, for special purpose fibres, mined ulexite $\left(\mathrm{Na}_{2} \mathrm{Ca}_{2}\right.$ $\mathrm{B}_{10} \mathrm{O}_{18} \bullet 16 \mathrm{H}_{2} \mathrm{O}$ ), manufactured borax pentahydrate $\left(\mathrm{Na}_{2} \mathrm{~B}_{4} \mathrm{O}_{7} \cdot 5 \mathrm{H}_{2} \mathrm{O}\right)$ and recycled glass cullet, for insulation wool. Boron is used because borate acts as a glass former and fluxing agent in glass melting, but boron compounds are relatively expensive compared to other batch components and are, therefore, only used if there are good technical and economic reasons. A phenolic resin binder, oils and other lubricants may be added during processing to reduce dust generation from the glass wool product (IARC 2002).

\subsection{Human boron exposure}

The general population is exposed to boron mainly from food and especially vegetarian foods. Foods rich in boron include fruits, leafy vegetables, mushrooms, nuts and legumes (peas, beans) as well as wine, cider and beer. Boron occurs mainly in foods of plant origin and as borate and boric acid. Rather few recent surveys exist of boron content of foods, thus the uncertainty is large (EFSA 2006). In addition, significant intakes may come with drinking water, and especially from mineral water. In some instances, exposure from the work environment, mineral supplements, cosmetics and other consumer products may be significant (IPCS 1998).

\subsection{Boron as an essential trace element}

Boron is a constituent of various natural biomolecules. Plant, animal and human biocompounds with adjacent hydroxyl groups may bind boron as ester complexes. Among the compounds examined, $S$-adenosylmethionine had the highest affinity for boron (Nielsen 2007).

Boron is an essential trace element for plants; however, it is toxic to plants when present in excess. Important functions of boron in plants (WSU 2007):

- Regulate metabolism of carbohydrates

- Activate certain dehydrogenase enzymes

- Aid in formation of pollen tube and feeder roots

- Are involved in translocation of calcium, sugars and plant hormones

- Facilitate the synthesis of nucleic acids

- Are essential for cell division and development

A transporter protein (BOR1) has been identified as being essential for efficient translocation of boron from roots to shoots during boron limitation (Takano et al. 2005).

Much information from the last 25 years indicates that boron may also be an essential element in humans, but, because of biochemical function, has not been defined for boron, since its nutritional essentiality has not been firmly established, although the existence of a specific mammalian borate transporter protein supports the earlier findings that the intracellular accumulation of boron occurs against a concentration gradient (Park et al. 2004; Hunt 2006; Nielsen et al. 2006). Boron has especially been demonstrated to be beneficial in:

- Metabolism of glucose. Boron may have a role in preventing diabetes.

- Metabolism and utilisation of calcium, magnesium, phosphorous and vitamin $\mathrm{D}$

- Boron helps in building and maintaining strong bones. Without small amounts of boron, bones would slowly break down and become brittle. 
- Metabolism of steroid hormones enhancing the response to steroid hormone therapy

- Proper brain function, and may increase mental alertness by improving psychomotor skills and cognitive processes of attention and memory.

In addition, boron may reduce human risk for prostate cancer (Barranco and Eckhert 2004).

\subsection{The hazard of boron compounds}

After years of discussions, the EU Technical Committee on Classification and Labelling of Dangerous Substances decided on September 8th, 2005, that some boron compounds (boric acid and borates) fulfil the criteria for 'Reproduction toxicity of Category 2' (Repr. Cat. 2), including the risk phrases: 'May impair fertility' ( $\mathrm{R}$ 60) and 'may cause harm to the unborn child' ( $\mathrm{R}$ 61), in relation to the EU Directive on Dangerous Substances (67/ 548/EEC) (European Commission 2006). This conclusion was based on the following outcome of studies with experimental animals:

- Fertility studies with rats and mice identified males as the most sensitive sex.

- In male rats, acute exposures to boric acid resulted in changes in sperm parameters and histopathological changes in the testes; these effects were irreversible at higher doses.

- Repeated exposure to boric acid affected the spermatogenesis and sperm quality of male rats, mice and dogs, resulting in either partial reduction in fertility or sterility, depending on the dose.

- During repeated exposure to high doses of boric acid, reproductive performance was also affected in female rats (caused by decreased ovulation).

- These effects on fertility occurred at doses well below signs of other toxicity.

- A No-Observable-Adverse-Effect-Level (NOAEL) of $100 \mathrm{mg} / \mathrm{kg}$ body weight per day was established based on these fertility studies.

- Exposure of rats, mice and rabbits to boric acid during pregnancy resulted in decreased foetal body weight and in foetal cardiovascular and rib malformations. The rat was the most sensitive species for this developmental toxicity.

- A NOAEL of $55 \mathrm{mg} / \mathrm{kg}$ body weight per day was established for prenatal effects.

The human data was considered inconclusive, but the available data on toxicokinetics and toxicodynamics did not indicate major differences between laboratory animals and humans regarding boron compounds. Therefore, the animal data was assumed to be relevant to humans.

\section{Materials and methods}

\subsection{Assumptions for calculation of exposure scenarios}

The manufacturing processes produces fibres with diameters that vary much within a given wool product and have an approximately log-normal distribution. In industrial plants, the highest concentrations of airborne fibres have been measured in fabrication, packaging and demolition. Typical average fibre concentrations range from 0.006 to $0.20 \mathrm{fibre} / \mathrm{cm}^{3}$. Even higher concentrations have been measured during installation of glass wool insulation, where concentrations of respirable fibre were 0.05-1 fibre $/ \mathrm{cm}^{3}$, with the highest concentration in attic insulation of existing buildings (IARC 2002). The TimeWeighed Threshold Limit Value (TLV-TWA) for glass wool is $1 \mathrm{fibre} / \mathrm{cm}^{3}$ or $10^{6} \mathrm{fibre} / \mathrm{m}^{3}$ (ACGIH 2007). In normal circumstances involving an exposure level for $8 \mathrm{~h}$ a day and 5 days a week, it is supposed to be the maximum occupational exposure and a worst-case scenario. In practice, exposure levels will mostly be ten to hundred times lower.

The deposition of inhaled fibres in the respiratory tract is a function of their physical characteristics (size, shape and density) and of the anatomical and physiological parameters of the airways. Retention and clearance of deposited fibres differ between fibre types related to the chemical and physical properties of the fibre, fibre size distribution, amount of fibre in the lung and time since exposure. Fibres with an average diameter of 1.5-2 $\mu \mathrm{m}$ and a length of $30 \mu \mathrm{m}$ can be considered typical for fibres of a modern glass wool insulation product for buildings. For fibres with an aerodynamic diameter of $2 \mu \mathrm{m}$, about $23 \%$ are retained in humans. The new glass wool products that have been developed and used in recent years contain fibres, which are more 'bio soluble' (IARC 2002).

The authoritative IARC evaluation of man-made vitreous fibres gives a range of densities of glass wool fibres of $2,400-2,600 \mathrm{~kg} / \mathrm{m}^{3}$ (IARC 2002). As a worst-case scenario, the density in the present evaluation is set to $2,700 \mathrm{~kg} / \mathrm{m}^{3}$.

The boron content in glass wool for building insulation is typically $5 \%$ as $\mathrm{B}_{2} \mathrm{O}_{3}$ or $1.5 \%$ as boron, and a maximal but uncommon content will be around $12 \%$ as $\mathrm{B}_{2} \mathrm{O}_{3}$ or $3.5 \%$ as boron (IARC 2002).

In exposure calculations, the daily 24-h human adult inhalation rate is often set to $20 \mathrm{~m}^{3}$ or $0.8 \mathrm{~m}^{3} / \mathrm{h}$, but the rate will be increased to around $2 \mathrm{~m}^{3} / \mathrm{h}$ during the moderate work load (USEPA 1997). Thus, using the increased rate during an 8-h work day, the total lung ventilation will then be around $16 \mathrm{~m}^{3}$. However, a work week is normally only 5 days. The selected scenarios are illustrated in Table 1. 
Table 1 Scenarios for exposure calculations

\begin{tabular}{|c|c|c|}
\hline Item & Typical value & $\begin{array}{l}\text { Worst-case } \\
\text { value used }\end{array}$ \\
\hline $\begin{array}{l}\text { Occupational } \\
\text { exposure } \\
\text { level for glass } \\
\text { wool fibres }\end{array}$ & 0.1 fibre $/ \mathrm{cm}^{3}$ & 1 fibre $/ \mathrm{cm}^{3}=10^{6} / \mathrm{m}^{3}$ \\
\hline $\begin{array}{l}\text { Density of glass } \\
\text { wool fibres }\end{array}$ & $2,400-2,600 \mathrm{~kg} / \mathrm{m}^{3}$ & $2,700 \mathrm{~kg} / \mathrm{m}^{3}$ \\
\hline Fibre diameter & $1.5 \mu \mathrm{m}$ & $2 \mu \mathrm{m}$ \\
\hline Fibre length & $30 \mu \mathrm{m}$ & $30 \mu \mathrm{m}$ \\
\hline $\begin{array}{l}\text { Retention of fibres } \\
\text { with an } \\
\text { aerodynamic } \\
\text { diameter of } 2 \mu \mathrm{m}\end{array}$ & $23 \%$ & $100 \%$ \\
\hline $\begin{array}{l}\text { Boron content in } \\
\text { glass } \\
\text { wool fibres }\end{array}$ & $\begin{array}{l}5 \% \text { as } \mathrm{B}_{2} \mathrm{O}_{3} \text { or } 1.5 \% \\
\text { as boron }\end{array}$ & $\begin{array}{l}12 \% \text { as } \mathrm{B}_{2} \mathrm{O}_{3} \text { or } 3.5 \% \\
\text { as boron }\end{array}$ \\
\hline Inhalation rate & $\begin{array}{l}0.8 \mathrm{~m}^{3} / \mathrm{h} \text { for } \\
24 \mathrm{~h} / \text { day }\end{array}$ & $\begin{array}{l}2 \mathrm{~m}^{3} / \mathrm{h} \text { for } 8 \mathrm{~h} / \text { day and } \\
5 \text { days/week }\end{array}$ \\
\hline
\end{tabular}

\section{Results}

\subsection{Calculations of worst-case exposures}

A fibre has the shape of a long, thin cylinder. The volume of a fibre (cylinder) can be calculated by the formula:

Volume $=\pi \times$ radius $^{2} \times$ height

$$
=\pi \times 1 / 2 \text { diameter }^{2} \times \text { length }
$$

Thus, for fibres with a length of $30 \mu \mathrm{m}$ and a diameter of $1.5 \mu \mathrm{m}$ or $2 \mu \mathrm{m}$, the volumes $\left(\mathrm{m}^{3}\right)$ are respectively:

(a)

$$
3.14 \times 0.56 \times 30 \times 10^{-18} \mathrm{~m}^{3}=5.3 \times 10^{-17} \mathrm{~m}^{3} .
$$

(b)

$$
3.14 \times 1 \times 30 \times 10^{-18} \mathrm{~m}^{3}=9.4 \times 10^{-17} \mathrm{~m}^{3} .
$$

The mass of one fibre can be calculated by the formulas:

$$
\operatorname{Mass}(\mathrm{kg})=\operatorname{density}\left(\mathrm{kg} / \mathrm{m}^{3}\right) \times \operatorname{volume}\left(\mathrm{m}^{3}\right)
$$

Using the calculated volumes and a worst-case density of $2,700 \mathrm{~kg} / \mathrm{m}^{3}$, the mass of one single fibre is then either:

(a)

$$
\begin{aligned}
& 5.3 \times 10^{-17} \times 2,700=1.4 \times 10^{-13} \mathrm{~kg} \\
& \text {, or }
\end{aligned}
$$

(b)

$$
9.4 \times 10^{-17} \times 2,700=2.5 \times 10^{-13} \mathrm{~kg} .
$$

A worst-case daily occupational intake of fibres can be calculated by the formulas:

Daily intake $(\mathrm{kg} /$ day $)=\operatorname{mass}(\mathrm{kg})$

$\times$ fibre concentration $\left(\mathrm{m}^{-3}\right)$

$\times$ inhalation $\operatorname{rate}\left(\mathrm{m}^{3} / \mathrm{h}\right)$

$\times$ exposure time $(\mathrm{h} /$ day $)$

Using the occupational limit value of 1 fibre $/ \mathrm{cm}^{3}=$ $10^{6}$ fibre $/ \mathrm{m}^{3}$, an inhalation rate of $2 \mathrm{~m}^{3} / \mathrm{h}$ and $8 \mathrm{~h}$ daily work, the total estimated mass of fibres inhaled during an 8-h work day will then be either:

(a)

$$
\begin{aligned}
1.4 & \times 10^{-13} \mathrm{~kg} \times 10^{6} \text { fibre } / \mathrm{m}^{3} \times 2 \mathrm{~m}^{3} / \mathrm{h} \times 8 \mathrm{~h}=2.2 \\
\times & 10^{-6} \mathrm{~kg} \text { fibre } \\
= & 2.2 \mathrm{mg} \text { fibre }
\end{aligned}
$$

, or

(b)

$$
\begin{aligned}
2.5 & \times 10^{-13} \mathrm{~kg} \times 10^{6} \text { fibre } / \mathrm{m}^{3} \times 2 \mathrm{~m}^{3} / \mathrm{h} \times 8 \mathrm{~h} \\
& =4.0 \times 10^{-6} \mathrm{~kg} \text { fibre }=4.0 \mathrm{mg} \text { fibre } .
\end{aligned}
$$

If, as a worst-case scenario, the retention and solubility of inhaled fibres in the lungs are set to $100 \%$, intakes will correspond to uptakes. With the normal boron content of $1.5 \%$ in glass wool fibres for building insulation, the extra daily occupational boron intake/uptake will be $0.03-$ $0.06 \mathrm{mg}$ B for 5 days a week. For more uncommon glass wool, with a maximum boron content of $3.5 \%$, the worstcase daily boron intake/uptake will be $0.08-0.16 \mathrm{mg} \mathrm{B}$.

\subsection{Other exposures to boron}

In order to assess if the exposure to boron through glass wool inhalation has any health significance, the calculated intakes above should be compared to other human boron exposures. The main boron exposure in the general population is from vegetarian food. WHO has estimated the average daily dietary intake to be $1.2 \mathrm{mg}$ boron/day (IPCS 1998). Another estimate, based on old data from the 1994 Total Diet Study in the UK, reports average daily boron intakes in adults of $1.5 \mathrm{mg}$ with a 97.5 percentile of $2.6 \mathrm{mg}$ (FNB 2000).

In addition, significant intakes may come with drinking water, especially from consuming mineral water. In some instances, exposures from mineral supplements, cosmetics and other consumer products may be significant. For example, individuals taking boron supplements, e.g. bodybuilders, may have an additional intake from that source of 
Table 2 Human exposures to boron

\begin{tabular}{lll}
\hline Exposure & Average daily boron intakes & Reference \\
\hline Food & $1.2-1.5 \mathrm{mg}$ (vegetarians more) & IPCS 1998; FNB 2000 \\
Drinking water & $0.2-0.6 \mathrm{mg}$ (more from mineral waters) & IPCS 1998 \\
Supplements, bodybuilders & $2.0 \mathrm{mg}$ (range 1-10 mg) & EVM 2002, 2003 \\
Cosmetics, consumer products & $0.1 \mathrm{mg}$ & IPCS 1998 \\
Soil & $0.47 \mathrm{mg}$ & EVM 2003 \\
Ambient air & $0.0005 \mathrm{mg}$ & IPCS 1998 \\
Workplace air & $0.0004 \mathrm{mg}$ at inhalation of $20 \mathrm{~m}^{3}$ air & IPCS 1998 \\
\hline
\end{tabular}

1-10 mg/day. The UK Expert Group on Vitamins and Minerals estimate a mean boron intake from supplements of up to $2.0 \mathrm{mg} \mathrm{B} /$ day (EVM 2002, 2003). Intakes from ingestion of dust and soils, and inhalation of ambient air, are considered negligible (Table 2).

\subsection{Safe boron intakes}

During the years, various organisations have recommended safe intake values for boron. Recently, the Scientific Panel on Dietetic Products, Nutrition and Allergies of the European Food Safety Authority (EFSA) has established the 'Tolerable Upper Intake Level' (UL) for the intake of boron as boric acid and borates of $0.16 \mathrm{mg} \mathrm{B} / \mathrm{kg}$ body weight per day or about $10 \mathrm{mg} \mathrm{B}$ /day for an adult weighing about $60 \mathrm{~kg}$ (EFSA 2006). The 'Tolerable Upper Intake Level' is the highest level of daily nutrient intake that is likely to pose no risk of adverse health effects for almost all individuals, and it corresponds to a Tolerable Daily Intake (TDI) or a 'No-Observable-Adverse-Effect-Level (NOAEL)' divided by uncertainty and safety factors. Some examples of safe level evaluations are shown in Table 3.

\section{Discussion}

Inhaled glass wool fibres will be dissolved in the lung and release boron compounds to be taken up by the body. The highest exposure will occur in occupational settings. The worst-case, occupational daily intake was calculated to $0.16 \mathrm{mg}$ boron during an 8-h work day for 5 days a week. This will result in an extra daily boron intake that only corresponds to about $10 \%$ of the average daily boron intakes through food and drinks of about $1.5 \mathrm{mg}$ in adults. The inter-individual variations in boron intakes from foods, water and supplements will be much greater than an eventual, very worst-case, additional intake of boron from inhalation of glass wool fibres.

In addition, the combined intakes $(1.7 \mathrm{mg} \mathrm{B} /$ day) are far lower than the 'Tolerable Upper Intake Level' of $10 \mathrm{mg}$ $\mathrm{B} /$ day for a person weighing $60 \mathrm{~kg}$, as recommended by the European Food Safety Agency. The potential boron intake from inhalation of glass wool fibres is also much lower than boron intakes by workers in the boron industry, whom at the present limit value will be exposed to $50 \mathrm{mg}$ boron 5 days a week, or 100 times more than the worst case for glass wool fibres. Furthermore, in practice, occupational exposure levels will be ten to 100 times lower than the occupational limit here used as a worst case.

The potential boron intake from inhalation of glass wool fibres could also be compared with boron intakes by workers in the boron industry exposed at the occupation limit value of $10 \mathrm{mg}$ boric oxide $/ \mathrm{m}^{3}$, corresponding to $3.1 \mathrm{mg} \mathrm{B} / \mathrm{m}^{3}$. With a lung ventilation of $16 \mathrm{~m}^{3}$ during a work day, this will result in a daily intake of about $50 \mathrm{mg}$ boron 5 days a week, or 100 times more than the worst case for glass wool fibres.

Table 3 Safe boron intake values

\begin{tabular}{|c|c|c|c|}
\hline \multirow[t]{2}{*}{ Name of value } & \multicolumn{2}{|l|}{ Safe boron $(\mathrm{B})$ intakes } & \multirow[t]{2}{*}{ Reference } \\
\hline & Per kg body weight (bw) & $\begin{array}{l}\text { Per adult person } \\
(70 \mathrm{~kg})\end{array}$ & \\
\hline WHO ‘Tolerable Daily Intake’ (TDI) & $0.4 \mathrm{mg} \mathrm{B} / \mathrm{kg}$ bw & $28 \mathrm{mg} /$ day & IPCS 1998 \\
\hline USEPA 'Reference Dose' (RfD) & $0.2 \mathrm{mg} \mathrm{B} / \mathrm{kg}$ bw & $14 \mathrm{mg} /$ day & USEPA 2006 \\
\hline The Food and Nutrition Board (FNB) 'Tolerable Upper Intake Level' & $0.33 \mathrm{mg} \mathrm{B} / \mathrm{kg}$ bw & $20 \mathrm{mg} /$ day $(61 \mathrm{~kg})$ & FNB 2000 \\
\hline The UK Expert Group on Vitamins and Minerals 'Upper Safe Level' & $0.16 \mathrm{mg} \mathrm{B} / \mathrm{kg}$ bw & $11 \mathrm{mg} /$ day & EVM 2002, 2003 \\
\hline 'Tolerable Upper Intake Level’ (UL) & $0.16 \mathrm{mg} \mathrm{B} / \mathrm{kg}$ bw & $\geq 10 \mathrm{mg} /$ day $(60 \mathrm{~kg})$ & EFSA 2006 \\
\hline
\end{tabular}




\section{Conclusions}

It is shown that the calculated worst-case exposure scenario only corresponds to $10 \%$ of the average daily boron intakes through food and drinks of about $1.5 \mathrm{mg}$ in adults. The inter-individual variations in boron intakes from foods, water and supplements will be much greater than the eventual, very worst-case, additional intake of boron from inhalation of glass wool fibres.

The estimated boron intake from inhalation of glass wool fibres in occupational or residential settings - even at the very unrealistic, worst-case scenarios and non-compliance with occupational limit values-will be insignificant and without any health risks. Therefore, any proposal to label glass wool products with the risk phrases R60 and R61: 'may impair fertility and may cause harm to the unborn child', because of the boron content, is unreasonable and not supported by the present scientific knowledge.

\section{Recommendations and perspectives}

The European Commission should ensure that the new EU hazard classification and labelling of boron compounds is not applied to commercial glass wool products for building insulation having a low content of boron. It is also an open question whether the borosilicate compound in the finished glass material is covered at all by the EU recommendations, which specify only the water-soluble compounds, boric acid and its borate salts.

Acknowledgement The research was supported by a grant from EURIMA, Brussels.

Open Access This article is distributed under the terms of the Creative Commons Attribution Noncommercial License which permits any noncommercial use, distribution, and reproduction in any medium, provided the original author(s) and source are credited.

\section{References}

ACGIH (2007) TLVs ${ }^{\circledR}$ and BEIs ${ }^{\circledR}$. Cincinnati, OH, USA

Barranco WT, Eckhert CD (2004) Boric acid inhibits human prostate cancer cell proliferation. Cancer Lett 216:21-29

European Commission (2006) Draft summary report from the session on classification of boric acid and borates. Meeting of the
Technical Committee on Classification and Labelling of Dangerous Substances and preparatory meeting for the Technical Progress Committee of Directive 67/548/EEC, Arona (Italy), September 8, 2005. ECBI/43/05. European Chemicals Bureau, JRC, Ispra, Italy, $21 \mathrm{pp}$

EFSA (2006) Boron, in tolerable upper intake levels for vitamins and minerals. European Food Safety Authority, Parma, pp 309322

EVM (Expert Group on Vitamins and Minerals) (2002) Revised Review of Boron. EVM/99/23/P.REVISEDAU2002. http://www. food.gov.uk/multimedia/pdfs/boron.pdf

EVM (Expert Group on Vitamins and Minerals) (2003) Report on safe upper levels for vitamins and minerals. http://www.foodstan dards.gov.uk/multimedia/pdfs/vitmin2003.pdf

FNB (Food and Nutrition Board) (2000) Dietary reference intakes for boron. Institute of Medicine, National Academy Press, Washington, DC, pp 510-521. http://www.nap.edu/openbook/ 0309072794/html $/ 510 . \mathrm{html}$

Hunt C (2006) Dietary boron: progress in establishing essential roles in human and animal physiology. In: Guyaguler $\mathrm{T}$, Karakas S, Ozdemir Z, Karakas A, Bukulmez A, Sonmezer O (eds), Proc 3rd Int Boron Symposium, November 2-4, 2006, Ankara, Turkey, pp 3-10

IARC (2002) Monograph on the evaluation of carcinogenic risks to humans, vol. 81: man-made vitreous fibres. International Agency for Research on Cancer, Lyon, 418 pp

IPCS (1998) Environmental Health Criteria 204: boron. International Programme on Chemical Safety, World Health Organization (WHO), Geneva, $201 \mathrm{pp}$

Nielsen FH, Stoecker BJ, Penland JG (2006) Boron as a dietary factor for bone micro architecture and central nervous system function. In: Xu F, Goldback HE, Brown PH, Bell RW, Fujiwars T, Hunt CD, Goldberg S, Shi L (eds), Advances in plant and animal boron nutrition. Boron 2005, September 10-13, 2005, Wuhan, China, pp 255-268

Nielsen FH (2007) Boron deprivation increases plasma homocysteine, a factor negatively associated with bone composition and strength [abstract]. J Fed Am Soc Exp Biol 21(5):A125

Park M, Li Q, Shcheynikov N, Zeng W, Muallem S (2004) $\mathrm{NaBC}_{1}$ is a ubiquitous electronic $\mathrm{Na}^{+}$-coupled borate transporter essential for cellular boron homeostasis and cell growth and proliferation. Mol Cell 16:331-341

Takano J, Miwa K, Yuan L, von Wiren N, Fujiwara T (2005) Endocytosis and degradation of BOR1, a boron transporter of Arabidopsis thaliana, regulated by boron availability. Proc Natl Acad Sci U S A 102:12276-12281

USEPA (1997) Exposure factor handbook. United States Environmental Protection Agency, EPA/600/P-95/002Fa, http://www.epa. gov/NCEA/pdfs/efh/front.pdf

USEPA (2006) Health effects support document on boron. United States Environmental Protection Agency, EPA-822-R-06-005. http://www.epa.gov/safewater/ccl/pdfs/reg_determine2/healthef fects_ccl2-reg2_boron.pdf

WSU (2007) Washington State University, Tree Fruit Research \& Extension Center. http://soils.tfrec.wsu.edu/webnutritiongood/ TreeFruitStuff/essential_elements/04boron.htm 